Kafkas Üniversitesi Sosyal Bilimler Enstitüsü Dergisi

Kafkas University Journal of the Institute of Social Sciences

Bahar Spring 2018, Sayı Number 21, 99-112

DOI:10.9775/kausbed.2018.008

Gönderim Tarihi: 13.02.2018

Kabul Tarihi: 21.03.2018

OPPOSING MALE DOMINANCE IN LADY LAZARUS

Lady Lazarus'un Erkek Hegemonyasına İsyanı

\title{
Erdinç PARLAK
}

Doç. Dr. Ordu Üniversitesi Fen Edebiyat Fakültesi, Yabancı Diller

Bölümü, İngiliz Dili ve Edebiyatı Anabilim Dalı

erdincparlak@gmail.com

ORCID ID:0000-0002-7184-8709

Belgin BAĞIRLAR

Dr. Öğr. Üyesi, Giresun Üniversitesi Fen Edebiyat Fakültesi, İngiliz Dili ve Edebiyat1

sakiroglu.belgin@gmail.com

ORCID ID: 0000-0001-5575-3227

Çalışmanın Türü: Araştırma

$\ddot{\boldsymbol{O}} \boldsymbol{z}$

Ataerkil toplumların, geçmişten günümüze değin en büyük yanlışı kadınlara tıpkı Simon de Beauvoir'in çalışmasına verdiği isim gibi İkinci Cinsiyet etiketini yapıştırmak olmuştur. Sosyal hayatta kendi cinsiyetinin varliğını kabul ettirmek ve kendilerini gerçekleştirmek için kadınlar, her daim bir mücadele içerisinde olmuşlardır ve Mary Wollstonecraft' in Kadın Haklarının Gerekçelendirilmesi' nden beridir bu mücadeleyi siyasal, sanatsal ve daha birçok alanda ortaya koymuşlardır. Bu çalışmada, Batı edebiyatın da 20. Yüzyılın en güçlü yazarlarından biri olarak kabul edilen Sylvia Plath'in Lady Lazarus adlı şiirin de kadının var olmak adına yeniden doğuş metaforu çerçevesinde yazdı̆̆ dizeleri, Fransız feministlerin ışlğı altında incelenecektir. Plath bu şiirde Incil'de geçen Lazarus'un yeniden doğuş hikâyesini bir Kadın Lazarus sembolüyle bağdaştırarak erkeği alt etme çabasına girişmiştir. Böylece, Kadın Lazarus erkek hegemonyasına meydan okuyarak yeniden doğmayı ve kadın kimliğini toplumda kabul ettirerek, mevcut ataerkil düzendeki baskılanıp ezilmiş kadın figürü yerine, güçlü kadın kavramını getirdiği yeni bir düzen kurmayı amaçlar. Ayrıca, Plath özgür olmak için seçtiği bir çözüm yolu olan intihar girişimini ve baskı altında yaşayan bir kadın olarak hissettiklerini eserine yansıtmıştır. Bu anlamda, Plath'in ataerkil düzen içerisinde karşılaştı̆̆l zorluklarl ve bu düzene karşı olan isyanını anlatan Lady Lazarus şiiri, cinsiyet eşitliği mücadelesine katkısı olan önemli bir eserdir.

Anahtar Kelimeler: Sylvia Plath, Lady Lazarus, feminizm, cinsiyet eşitliği

Abstract

The chief wrongdoing of patriarchal societies throughout history and into the present day are their labelling of women as the second sex-akin to Simon de Beauvoir's magnum opus of the same name. Women have consistently struggled in order to put across the existence of their own gender, as well as to make themselves present within the strata of social life. They have given voice to this struggle through politics, art, and a great many other means ever since Mary Wollstonecraft's penning of A Vindication of the Rights of Women. In this paper, the existence of woman in the poem Lady Lazarus by Sylvia Plathwho is accepted to be one of the strongest writers of the $20^{\text {th }}$ century Western Literaturewill be examined under the lens of French Feminism. In this poem, Plath attempts to dispose men by correlating them with a female Lazarus symbol, as taken from the 
resurrection story of Lazarus in the Bible. She hence aims to bring the concept of the woman to a new level in place of the pre-existing patriarchally oppressed female figure by challenging male dominance and by establishing the re-birth of as well as identity of women in society. Plath moreover conveys in her poem the emotions of a woman who selects suicide as a means of freedom and lives under pressure. Lady Lazarus in this context, in its voicing the challenges Plath faced within patriarchal society and her revolt against it, is an important piece that contributes to the struggle for gender equality.

Keywords: Sylvia Plath, Lady Lazarus, feminism, gender equality

\section{Introduction}

In remembering the industrial developments of the $19^{\text {th }}$ century, the $20^{\text {th }}$ century too had made its mark on history with the First and Second World Wars. People had become estranged from one another due to the effect of the worldwide Great Depression that had begun in 1929 and lingered throughout the 1930s, as well as the many cultural, social, and economic changes that took place following World War II. Along with the changes in industry came the cheapening of the working power of man as machines had begun to take their place, thus leading to a spike in unemployment as a direct result. Both the international Cold War from 1947 until 1991, as well as rapid advancements in technology had distanced people from one another and had trapped them within their own isolation. Sylvia Plath (1932 - 1963), who was one of the greatest American female writers of the $20^{\text {th }}$ century, had been witness to these important historical shifts as part of living within that era. Moreover women like Plath who were caught dead in the middle of this depression had taken on the responsibilities of not only themselves but also those of their partners and children; had become imprisoned within the household in order to provide for their welfare by carrying out the most difficult role of protecting the family order. In this paper, poetry, or more specifically Path's Lady Lazarus -in being one of the foremost classical examples of confessional poetry-has been approached through a critical lens; and French feminist theory has been used to answer queries as to what the place of $20^{\text {th }}$ century women was within the patriarchal system, how women were objectified, and to what degree were women's experiences reflected in literary works. Within this context, firstly, this paper has attempted to provide theoretical information pertaining to the concepts of feminism as well as French feminism. Following that, as probing and understanding the messages of Plath's Lady Lazarus as well shadowing the traces and traumas within her life without prior knowledge will prove difficult, French feminists such as Cixous, Irigaray, and De Beauvoir have been progressively selected in order to touch upon the various turning points along Plath's life as well to analyse her poem.

Throughout history, women-for whom society has turned a blind 
eye to and have been treated as second class-have lustfully thrown themselves in front of our eyes in order to be noticed within the situation they've found themselves in, and have revolted in order to possess the same rights as men. More broadly speaking, the term 'feminism' has been given to women's struggle of laying down the principles for economic, social, and political rights and equality within the patriarchal order. Charles Fourler (1808), who was the first to coin this term, had stood for women needing to have equal rights in order for society to advance. Karren Offen, defines feminism as being defiance, stating that "Feminism is the name given to a comprehensive critical response to the deliberate and systematic subordination of women as a group by men as a group within a given cultural setting" (Offen, 2000, p. 20) Judith Evans evaluates feminism as being more about possessing equal conditions, noting that "women seek for the same opportunities and privileges the society gives to men" (Evans, 1995, p.7). It has been observed feminist movements, whereby women had become aware that their freedoms were limited on a number of dimensions - had started to quiver towards the end of the $19^{\text {th }}$ century. These movements have thus been classified as first, second, and third wave feminism. Hewitt (2010, s.4), in stating that "each wave overwhelms and exceeds its predecessor", defends that each wave is in fact interconnected with one another. Whist first wave feminism-which covers the feminist movements of the $19^{\text {th }}$ century - contains the 1848 Seneca Falls Convention calling for women to have equal rights, theorists treat the continuation of this struggle throughout the 1960 s as being second wave feminism. Betty Friedan, who had found herself stuck in problematic marriages as well as under the patriarchal system, and who was moved by women's misery, had written a book in 1963 titled "The Feminine Mystique", touching upon the subject of women being forcefully being cornered into the household. As all of the negative economic conditions following the war had caused people to become estranged and thus distant from one another, this too meant their relapse into states of loneliness and melancholy. Women, had found themselves working for the sake of contributing to the economy of the family, were however nether able to gain the right to earn the same standard of living as men, nor were their chances of getting promoted on par with men. For this reason, the 'National Organization for Women' was established in the United States in 1966, which had sided with the notion that women and their bodies should not be seen as being objects that serve the patriarchal system. During the 1990s, 'third wave feminism', or by its other name 'post-modern feminism' made its way into the American spotlight. Naomi Wolf (1991) and Rebecca Walker (1992), who both reject the term 
'post-modern feminism', prefer the term this new movement as being 'third wave feminism', which is more about the diversification of women's problems in connection to changing world conditions. Third wave feminism, which is hidden within language and focuses on the details of how women are alienated, had dealt with "a wide range of feminist perspectives... a spectrum of racial, ethnic, gender, and sexual identites" (Henry, 2004, p. 32). According to Lisa Albrecht, as second wave feminism only zeroed in on the white/Caucasian women, third wave feminists thus strut themselves being "against second wave feminism." (Gillis, 2007, p. 7). On the other side of the fence, writers such as Wolf and Walker proclaim that second wave feminism was the mother of the emergence and development process of third wave feminism. (Henry, 2004, p. 27).

Regardless of feminist approaches being coined differently by different theorists, the aim of all of them remains the same from socialist, liberal, radical, cultural, material, and psychoanalytical standpoints. The term French feminism had first started to be used during the 1970s in France, by French feminists, via the "Mouvement de libération des femmes". Even if the use of this term has been encountered in relatively recent history, French women's battle for equality in fact begins with the publishing of a book titled City of Ladies that strung together the letters of Christine de Pizan penned in 1405, telling about the unjust actions of men towards women. During the latter half of the $19^{\text {th }}$ century, French feminists and theorists such as Simon de Beauvoir, Luce Irigaray, Hélène Cixous, and Catherine Clément, who were firmly set in having their voices heard and heatedly expressing their emotions against the inequalities of the $20^{\text {th }}$ century, had begun to sharply criticise male culture by decisively standing up against the patriarchal system.

French feminism had focused on two different areas, "materialist feminism" and "psychoanalytic feminism." Materialist feminism talks about the social and economic pressure hanging above women's heads; whilst psychoanalytical feminism concentrates on the experiences of women under male dominance as well as the created influence of experiences have upon them. Theorists and philosophers within French feminism had not only criticised the male sex, they had also directed much of their energy to the mother figure and the role of the mother at the same time by securitizing on language and writing. Within this context, the significance of the role of the mother within the female realm was stressed under the light of Lacan-who was one of the most influential psychoanalytic theorists of the period. According to French feminism, patriarchal beliefs support the divergence 
between woman and men. Simon de Beauvoir, who in her 1949 book "The Second Sex" writes that "One is not born, but rahter becomes, woman" (1973, p. 301), states that women are being alienated within patriarchal society, and defends that women need to exert themselves until they succeed in order to set themselves free. Hélène Cixous $(2003$, p. 3), the writer and feisty feminist who rose to fame with her 1975 book "The Laugh of Medusa", is aware of the of power of masculine language over society. In merely wanting to even out the balance between men and women, she stresses that writing is the best way for women to share their experiences with one another, as well as for them to talk about the difficulties they face within the era they're living. Luce Irigaray (1985, p. 122-3), who is known for her massive contribution to French feminism as well as who is at the same time a philosopher, has stated that the gender differences have been willingly established by the patriarchal system in terms of social roles, status, discourse and even language. For this reason, she argues that women, by making a point of realising themselves, need to start with language in order to overcome this. Because, according to Irigaray (1994, p. 100), there is no such thing as a happy mother and daughter relationship either in history or in even the Old Testament. In this context, Susan Archer Mann (2012, p. 230), states that the common direction of French feminists such as Luce Irigaray, Julia Kristeva, and Hélène Cixous is their calling women to translate their doings into writing in order to recreate their womanhood in a more powerful fashion. Plath, who had awoken to this call and who had carried the trail of her life into her writing, had created many a work in the name of transforming herself.

\section{Sylvia Plath and Lady Lazarus}

Born in America in 1932, Plath was the child of a middle class family. Her first ever poem got published in The Boston Sunday Herald when she was 8 years old. Alongside her mother Aurelia and father Otto, she had also had a brother named Warrens. Her father Otto was born in a village in East Germany; and had immigrated to America in 1900, settling in New York. Otto had met Aurelia in 1929; and the two got married in 1932. Plath in fact was not the child of a happy family. Aurelia, too, was a women trapped at home and kept in line by male dominance. Otto had not wanted his wife to teach German, and had pressured her into being a housewife. Sylvia - in being very fond of her father - had suffered a traumatic blow because of his death when she was young; she never forgave him for this. She wrote poems titled "Daddy", "Edge", and "The Beekeeper's Daughter" expressing her loathing of him because he abandoned her when she was little. The relationship between Sylvia and her mother is interesting. Plath, 
out of never wanting to mention to mother about her failures in life, wrote the poem "Medusa" (1965) which talks about her not wanting to be like her mother. In 1977, an anthology of short prose was published titled Johnny Panic and the Bible of Dreams, in which she found the opportunity to voice the problems she had had with her mother.

In 1956, Plath had married Ted Hughes, who was one of the most popular poets of day; which thus had laid the groundwork for herself living through power struggle akin to the one between her mother and father. In other words, Plath, in realizing/transforming herself, had taken upon herself the compulsory role of being both a successful poet in eyes of the public, as well as being June Cleaver at home. She had two children named Freida and Nicholas. Although the first part of their marriage had swimmingly carried along, six years into things Sylvia in 1962 had learned about the relationship between Ted and family friend Assia Wevill. This had marked the second traumatic blow in Sylvia's life. After the two divorced, at age 30 Plath had, as she herself once put, succeeded in being "set free"-committing suicide by asphyxiating herself with gas. Before she died, she had endured the crushed dream of not being able to achieve the success she wanted as a female writer - this despite the publishing of a book of poetry titled "The Colossus" (1960), as well as a novel titled "The Bell Jar" (1965). Ted Hughes, who was blamed by a number of people for Plath's suicide, had collected and published another book of Plath's poetry titled "Ariel" (1963). Unfortunately, it's only after her death that Plath's value as a writer could be recognized.

Plath's pieces even today are interpreted by those reading her literature with great interest. Templer, (2009, p. 7) who has given prominence to Plath in Women's Studies as well as through her research, states that: "Plath is considered as the precurser of modern feminism by many people" Kizılarslan (2008), openly distinguishes Plath from other poets in defining her as being "a famous poet who became as known for her tragic suicide as she was for her marginal, dark poetry." Plath, according to Butscher, "a confessional poet who was consciouslu dedicated to fusing biography with poetry to create an enduring legend" (1976, p XI). Writers and poets of the confessional writing movement, which had gained popularity at the beginning of the $20^{\text {th }}$ century, used their own inner worlds as well as their experiences with the outer world as a resource for their works. Within this context, Plath, who was among (other) $20^{\text {th }}$ century female American writers such as Anne Sexton and Elizabeth Bishop, uses her powerful pen to pour onto paper her experiences, feelings, and thoughts 
rather than tell them to others. Moreover, in an interview she'd done with $\mathrm{Al}$ Varez, Plath had clarified her actual intention, explaining that "I have to live to keep my self from past" (Perloff, 1972, p. 508). Here, a parallel can be drawn between Plath's literature, Anne Saxon-who, like Plath, had committed suicide - as well as the Turkish poet Nilgün Marmara, who too was very much a fan of Plath. Marmara had jumped off the $5^{\text {th }}$ floor of her apartment building and killed herself, never completing her paper titled "An Analysis Sylvia Plath's Poethood Within the Context of Suicide". To paraphrase, both Marmara and Saxon had followed in Plath's footsteps and set themselves free after purging themselves from the shadows of the past through writing.

\section{Lady Lazarus}

Lady Lazarus, which is comprised of 28 stanzas, appears in the book "Arial" (1965) containing Plath's poems as compiled by Ted Hughes. Lady Lazarus is Plath's final poem-albeit one of her most striking ones as well. Butcher (1976, p. 316) is of the opinion that Plath's "The finest and fiercest poems from the last six months of Sylvia's life, such as "Lady Lazarus", "Mary's Song", "Fever 103" will tend always to commence with a private revelation". Wagner Martin, (1987:59) puts forth that Lady Lazarus is one of her most meaningful poem in terms of taking vengeance against the patriarchal system. In Lady Lazarus Plath fulfils her dream and she creates a new world that she dreams and a new strong female in her poem.

Plath was influenced by the Biblical story of Lazarus's Death and Resurrection (John 11: 1-45, KJB). Lazarus was an $11^{\text {th }}$ century monk who was looked highly upon by Jesus. Jesus learns that Lazarus has taken ill; however by the time he reaches Lazarus he learns that he's died. Four days following his death, Jesus performs a miracle and resurrects Lazarus from the dead. Lazarus and those who believe in this resurrection come to understand the power of God through this miracle. This story had had a profound impact upon Plath. It is thus possible to draw a similarity between Plath, who becomes famous after her death and immortalizes, and Lazarus. Plath, like Lazarus, has been resurrected from the dead in gaining the credibility she deserved through the publishing of her works following her suicide, as well as in being a source of inspiration to many a feminist writer and reader.

Cixous (2003, p. 55) argues in the literary sense that when the past is looked back upon, that everything is met with gratitude because, in principle, there is a relationship between men and all of what is being told in terms of their anguishes, the uniqueness of their desires, and God within those 
desires. In other words, where men had represented strength, war, and the sun in literature, women were marginalized with words depicting delicateness, the moon, and fragility. Cixous (2003), like Irigaray (1985), stands for the need to eliminate taboos and to create feminine language in order to demolish these age-old linguistic patterns by inviting all women to write. Despite the story that Plath is influenced by being about the resurrection of a male, she changes the states of manhood and womanhood within masculine language, and protests the ossifying patriarchal system by making the hero (Lady) Lazarus female, and gives a voice to all women who live within that system and cannot realize their potentials under the pressure of that system.

Plath kicks off her poem by talking about an attempt at suicide every 10 years. For Plath, who likens the result of these attempts in which she deems as unsuccessful being "sort of walking miracle", death means conquering a grueling rather than weak task and becoming free. This is because Plath views the chance for women to transform themselves in this male-dominated world as being impossible. In turn, for Plath, embracing death is the only road to independence. According to Plath, Lazy Lazarus will resurrect out of death stronger and free, rather than evaporating into smoke. In this sense Plath-who writes her poem as an appeal to all women-views women living under the conditions of this patriarchal system as being strong enough to be able to decisively continue down their own paths, as well as to struggle for resurrection in a sense by clarifying their goals.

"Bright as a Nazi lampshade/My right foot/a paperweight/My face a featureless, fine/Jew linen." Plath draws attention to women's being forced to live under pressure as well as to their weakness by using objects such as lampshade, a paperweight, and linin as a reference to their being fragile and weak by objectifying every inch of their body, typical of what the patriarchal system as done to them. On the other the hand, she makes reference to the Holocaust that had taken place over the course of the Second World War, and that is one of the most painful events in history in terms of its psychological and sociological aftermath on humanity. As Cixous (2003, p.3) said, "seeing the world nude, that is, almost to e-nu-merating the world, with the naked, obstinate, defenceless eye of my nearsightedness...The world written nude is poetic" is the manifestation of reality. Plath, in being alive during that period, reflects this traumatic evet through which she had lived onto her poetry via the art of metaphor. In Daddy (1965), whereby she had previously used the Holocaust metaphor as a reference to her father, in 
fact is appealing to the patriarchal system as a whole. She is stamped over in the face of the Nazi-like pressure of men and their cruelty in comparing women herself and other women to the Jews in order to emphasise the emotional purgatory through which she has/they have withstood. However, Lady Lazarus, who at the end of the poem is resurrected and who obtains the power she desires, will stamp out male hegemony. Path thus takes the axe to the grind in her poem and speaks on behalf of women through her imagery.

Plath, in declaring men to be the enemy by saying "Peel off the napkin/Oh my enemy", as well as in asking "Do I terrify-?", she mockingly approaches male hegemony through an ironic play of words and, when she lifts the veil, she is unable to avoid asserting that the body in which she encounters is the same as her own. One gets the sense from the line "And I am a smiling woman", that the fear of death is meaningless to Plath. She implies that she is a happy woman, for death to her expresses nothing more or nothing less than embracing independence.

I am only thirty.

And like a cat I have nine times.

This is Number Three.

What a trash

To annihilate each decade.

In these lines, Plath is putting depth of her emotions at the forefront by depicting in her poem the significant events in her life, the feelings that she had kept hidden, and her thoughts. She mentions her repeatedly unsuccessful suicide attempts every decade by comparing herself to a cat. Plath is unable to succeed in being set free "for now" on the third suicide attempt, indicating that she will try yet again in order to embrace freedom before it's too late. Plath, in screaming out to the crowd of the patriarchal system within which she's living exclaims that "I am the exact same woman" by yet again pointing out that her hands, feet and knees are like everyone else's. According to both Simon de Beauvoir (2011) and Luce Irigaray (1994), the biological difference between women and men is something nature, however this this does not entail that there be a difference in terms of equality. According to De Beauvoir (2011, p. 483), "men hold the upper hand on culture", and believes that they are even more different when one takes their power away. Plath underlines "The big strip tease" that in allowing every piece of herself to be seen. Wagner (1982, p. 52) argues that that Plath's use of the word "striptease" is referencing sexuality as well as the elevation of male dominance. On the other hand, one can extract from these lines that the upheaval that Plath is within, the extent of pressure she 
feels, and her being marginalized is in fact on par with everybody else. She actually arrives at this insurgence when she was only little through the deep sadness that she experiences over the death of her father. Plath begins to challenge this when she is all but 10 years of age.

The first time it happened I was ten.

It was an accident.

The second time I meant

To last it out and not come back at all.

I rocked shut.

As a seashell.

They had to call and call.

According to Cixous, Plath dubs the drowning scare that she lived through the year her father died as an accident. In saying "The second time I meant", at the age of 21 she had overdosed on sleeping pills and fell down the stairs, "rocked shut, as a seashell." Plath is decisive in wrapping up this artistic project in confessing that her suicide attempts were in fact works of art. Even though for most people death is a massive fear, Plath exclaims that death itself is the feeling of reality-for it is only through this solution that she can rescue herself from her painful experiences, her emotions, and from pressure she is under. Moreover, death for Plath is a form of bliss she couldn't find whilst alive. She exalts death in her poem to such an extent that the poet, who in being unable to avoid the negativity that she feels whilst on earth, compares her home to a jail cell.

It's easy enough to do it in a cell.

It's easy enough to do it and stay put.

It's the theatrical

Comeback in broad day

To the same place, to the same face, the same brute

Amused shout

Plath - a housewife with two children-would return every day to the home she likened to a jail cell, tired of and turned off from seeing the same face (her spouse Ted), and from wailing over a "brute" in a relationship that was going south. Moreover, where Ted was freely able write as he so loved, and even though Plath too would translate her wild creativity into words for short periods at a time from the cage that she was forced to live in, her works her no wear near as appreciated as those of her husband's given the conditions she was working under. This was why for Plath it was "easy enough to do it and stay put", considering she never once 
saw her work appreciated in a male dominated world, that she was speaking up against the conditions of the patriarchal system, and that she was trying to withstand a miserable marriage. For her, strength meant having every one of her attempts being met with failure and then coming back to life. To the poet this is dream crushing, even though to those around her this is a "miracle" of sorts. For this reason, in referring to the doctor who was to bring her back to life as "Herr Doktor", as well as in referring to the nemesis that were the men who caused her to alienate her own self as "Herr Enemy", she blamed and took a stand against the patriarchal order for its forcing her to stay alive and for the pain it had caused her to endure. Furthermore, Plath-who, like Lady Lazarus, had come back to life-is now even stronger, more venomous, and more decisive to have those who inflicted this upon her pay with their lives.

I am your opus,

I am your valuable,

The pure gold baby

That melts to a shriek.

I turn and burn.

Plath, in blaming male hegemony as being the cause of her suicide attempts, traumas, and marginalization, and in (d)evaluating women through masculine eyes as being "I am your valuable... the pure gold baby", stresses that women living under male hegemony are seen as being as valuable as objects, and as care-dependant toy babies. Luce Irigaray (1985, p 78) states that: "the feminine finds itself defined as lack of deficiency, or as imitation and negative image of the subject, they should signify that with respect to this logic a disruptive excess is possible on the feminine side". Thus female writers continue to write instead of creating their own language and define women with male images.this causes the continuity of male superiority. In once again reiterating the words Irigaray uses in order to describe the women of the patriarchal system, Plath too is unable to step out of this system, and objectifies women by using masculine-type linguistic metaphors such as "valuable" or "pure gold baby" etc. Moreover, the "pure gold baby" thus-in any sort of revolt- "melts to a shriek", losing its lovability and value to the mutiny, and is a woman who has been exposed to every negative description in the book. De Beauvoir (2010, p. 297) underlines that "Antifeminists object that cultured and intelligent women are monsters: the whole problem comes from the fact that they are still exceptional". Because of this and as Plath indicates, women are take all of the negativity upon themselves 
because they are unaccustomed to being up in arms. Critic Liz Frost (2000, p. 52), judges Plath for her being unable to free herself because of her use of oppressive patriarchal figures in her poem, and defends Plath's in fact being caught in the web of male hegemony. Conversely, the principal woman of the poem isn't the one who is being described for her weakness and fragility, but rather the strong and determined image of Lady Lazarus appearing at the end of the poem. She, in saying "I turn and burn", sees her struggle under oppression, her lack of a heard voice, and the traumas that she's lived through wherever she looks - be it in her childhood, in her marriage, or under oppression - and thus her anger only elevates. Plath, is well aware of how they have been diversely portrayed throughout history, as well as how they have been shrugged off in the name of being able to show just how different women are from men in society. For this reason, she once again makes it clear in her poem that women are not different from one another, and that no matter how deep into the issue that they dig that they won't find anything beyond meat and bones. She then warns in a threating "beware":

[Herr God, Herr Lucifer

Beware

Beware.]

Out the of ash

I rise with my red hair

And I eat men like air.

Again Lady Lazarus, who emerges stronger and more threatening through resurrection, takes a firm stand against the patriarchal system. Lady Lazarus's red hair warns men of coming danger. Plath's use of the red hair metaphor can be interpreted in any of a number of ways. According to Ryan, who says that "red does have differing meanings and can be appropriated to emphasize difference" (2003:72), indicates that Plath is (red hair) emphasizing her eccentric resurrection and strength. From a sexual angle, the adjective "red" could have been used in order to heighten the effectiveness or to arouse interest. From another vantage point, Plath, who in threatening the whole of patriarchal society by uttering "Beware" in the previous stanza, Plath could have used the colour red in as a sign of forthcoming danger to the patriarchal system. Lady Lazarus's goal upon coming back from the dead is set is crystal clear, she is more resolute, and obtains her strength from eliminating the patriarchal order. Plath therefore accomplishes a female revolt against male hegemony, and celebrates the victory of this by wiping men out.

The art of poetry as a branch of literature that has remained at the 
helm of every period across time is one literary form that truly has the power to influence society. With this reason in mind, many a literary critic has probed the works of poets, and have tried to comprehend what the poet is trying to communicate through her/his poetry. During times of war across the planet, poems laced heavily with heroic content were penned; whilst during the years surrounding the industrial revolution, poetry dealt more with the working class and its problems. Works centered on gender equality and women's rights emerged with the French Revolution, and continued its course within the framework of poetry's ever changing form over each successive time period. Plath, through Lady Lazarus, verbalizes the place within society that the $20^{\text {th }}$ century woman held that how she was perceived. According to her, a woman is like a helpless and defenceless baby, still forcefully stuck in a cage and shut off from the world, and tasked with providing the needs of her children and husband. Plath-who uses the negativity she's endured and her experiences a resource for her poetrygives voice at the same time to her abhorrence towards male hegemony, as well as talks about her suicides, about suicide as being the only way out rather than being a weakness, and the marriage that left its mark on her. According to Irigaray, women are only able to express themselves in secret and hidden away from view, and that the reason why women take on an enemy-like stance is that they are expressing their emotions stemming from being forced into oppression by men. Lady Lazarus too was a means for Plath to let out her sadness and pain which had in part stemmed from open hostility that she had had towards her father, her husband, and all men in general. What is more, she depicts women as being as defenceless as the Jews in sharpening these feelings through the use of Holocaust-related metaphors and equating mean to being as cruel as the Nazis. We observe a common theme of death in Plath's poetry; however, death in Lady Lazarus is different from death Plath's other works in that she finds closure through resurrection. Plath, in being influenced by the story of Lazarus in the Bible as well as in using the strength hatred has given her, closes destroys what's left of the patriarchal system at the end of her poem by making Lady Lazarus a resilient symbol. Annihilating male hegemony is the only way that Plath can transform herself and hence achieve her goal to rescue womankind.

\section{REFERENCES}

Butscher, E. (1976). Sylvia Plath: Method and Madness, Schaffher Press.

Cixous, H. \& Calle-Gruber M. (2003). Hélène Cixous Rootprints: Memory and Life Writing. Taylor \& Francis, London.

De Beauvoir, S. (2010). The Second Sex, Vintage Book, New York.

Evans, J. (1995). Feminist theory today. An Introduction to Second-Wave 
Feminism, London.

Frost, L. (2000). Every woman Adores a fascist: Feminist visions of fascism from three guineas to Fear of Flying. Women's Studies, 42, 37-69.

Gillis, S., Howie, G. \& Munford R. (2007). Third wave feminism: A critical exploration. Palgrave Macmillian, New York.

Henry, A. (2004). Not my mother's sister: Generational conflict and third wave feminism. Indiana University Press, Indiana.

Hewit, N. (2010). No permanent waves: Recasting histories of U.S. feminism, Ruther University Press, London.

Irigaray, L. (1985). This sex which is not one. Cornell University Press, Newyork.

Kızılarslan, Y. (2008). Cadıların lanetlediği bir masal prensesi:Sylvia Plath, BIA Haber Merkezi, http://bianet.org/biamag/dunya/110449-cadilarinlanetledigi-bir-masal-prensesi-sylvia-plath

Mann, S. A. (2012). Doing feminist theory: From modernity to postmodernity. New York, NY: Oxford University Press.

Offen, K. M. (2000). European feminisms, 1700-1950: A political history. Stanford University Press.

Perloff, M.G. (1972). A ritual for being born twice: Sylvia Plath's "The Bell Jar". Contemporary Literature, 13 (4), 507-522.

Ryan, J. (2003). Chinese women and the global village: An Australian site. University of Queensland Press.

Templer, B. (2009). Poetry in motion: A multimodal teaching tool. Humanising Language Teaching, 11.

Wagner, L.W. (1982). Plath's Lady Lazarus. Explicator, 41 (1), 50-52.

Wagner, L.W. (1984). Critical essays on Sylvia Plath. Twayne Publishers.

Wagner-Martin, L. (1987). Sylvia Plath: A Biography. New York: Simon and Schuster. 